\title{
Perancangan Aplikasi Simulasi Penyelamatan Diri Dari Gempa Bumi
}

\author{
Azizurrahman Marzali ${ }^{1}$, Daniel Udjulawa ${ }^{2}$, Yoannita ${ }^{3}$ \\ ${ }^{1,2}$ STMIK GI MDP, Jalan Rajawali No.14 Palembang, 0711-376400 \\ ${ }^{3}$ Program Studi Teknik Informatika, STMIK GI MDP, Palembang \\ e-mail: ${ }^{1}$ azizurrahman98@mhs.mdp.ac.id, ${ }^{2}$ daniel@mdp.ac.id, ${ }^{3}$ yoannita@mdp.ac.id
}

\begin{abstract}
Abstrak
Menurut The World Risk Index tahun 2019, Indonesia berada pada peringkat 37 dari 180 negara paling rentan bencana. Pada tanggal 5 Agustus 2018 gempa bumi di Lombok menelan korban sebanyak 259 orang meninggal dunia, dan 1.033 mengalami luka berat. Kurangnya kesiap siagaan dan edukasi mengenai bencana gempa bumi menjadi salah satu faktor penyebab banyaknya jumlah korban. Maka dari itu dibuatlah sebuah aplikasi simulasi yang ditujukan untuk mengedukasi masyarakat supaya dapat mengetahui apa saja yang harus dilakukan pada saat terjadi gempa bumi. Aplikasi ini dibuat menggunakan metode prototyping untuk melakukan identifikasi masalah yang ada pada setiap kejadian gempa bumi. Tujuan dari pembuatan aplikasi ini adalah untuk memberikan pengetahuan tentang bagaimana cara menyelamatkan diri dari gempa bumi. Aplikasi ini berbentuk game yang mempunyai sudut pandang First Person yang mempunyai empat stage dan setiap stage mempunyai beberapa misi. Pemain harus menyelesaikan seluruh misi pada setiap stage agar dapat melanjutkan ke stage selanjutnya. Hasil dari penelitian ini yaitu menghasilkan sebuah aplikasi simulasi dalam cara menyelamatkan diri dari gempa bumi. Berdasarkan uji Black-Box yang telah dilakukan, diperoleh hasil uji coba bahwa aplikasi ini dapat dijalankan dengan baik dan sesuai dengan tujuan.
\end{abstract}

Kata kunci-Unity 3D, Aplikasi Simulasi, Gempa bumi, Aplikasi Edukasi.

\section{Abstract}

According to The World Risk Index 2019, Indonesia was ranked 37 of 180 countries most vulnerable to disasters. On August 5, 2018 the earthquake in Lombok killed 259 people, and 1,033 were seriously injured. Lack of attention and education regarding earthquake disasters is one of the factors causing the large number of victims. Therefore, a simulation application is made that is intended to educate the people so that they can find out what to do in the event of an earthquake. This application is made using the prototyping method to identify problems that exist in every earthquake event. The purpose of making this application is to provide knowledge about how to save yourself from earthquakes. The form of application is a simulation game that has a First Person perspective, which has four stages and each stage has several missions. Players must complete all missions on each stage in order to proceed to the next stage. The result of this research is to produce a simulation application in how to save yourself from earthquakes. Based on the Black-Box testing that has been done, the result of this test shows that the application can run properly in accordance with the objectives.

Keywords-Unity 3D, Simulation Application, Earthquake, Educational Application. 


\section{PENDAHULUAN}

Bencana alam merupakan bencana yang diakibatkan oleh peristiwa yang disebabkan oleh alam berupa banjir, tsunami, gempa bumi, gunung meletus dan tanah longsor. Gempa bumi merupakan peristiwa bergetarnya bumi yang diakibatkan oleh pelepasan energi dari dalam bumi secara tiba-tiba yang disebabkan oleh patahnya lapisan pada kerak bumi. Indonesia merupakan salah satu daerah rawan terjadinya gempa bumi karena Indonesia memiliki tiga jalur pertemuan lempeng tektonik, yaitu: Lempeng Eurasia, Lempeng Indo-Australia, dan Lempeng Pasifik [1].

Menurut The World Risk Index tahun 2019, Indonesia menempati peringkat 37 dari 180 negara yang paling rentan bencana [2]. Berdasarkan data Badan Nasional Penanggulangan Bencana (BNPB) menyebutkan pada tanggal 29 Juli 2018 terjadi gempa bumi berkekuatan 6,4 Mw yang terjadi di Pulau Lombok 20 orang meninggal dunia, serta 401 orang lainnya mengalami luka-luka. Lalu pada tanggal 5 Agustus 2018 gempa bumi kembali melanda lombok dengan kekuatan $7 \mathrm{Mw}$, Badan Nasional Penanggulangan Bencana (BNPB) kembali menyatakan bahwa 259 orang meninggal dunia, dan 1.033 mengalami luka berat [3]. Dalam dua kejadian gempa bumi yang melanda kota Lombok ada banyak sekali warga yang menjadi korban, mulai dari luka ringan sampai mengalami kematian, dalam hal ini ada baiknya warga.

Game edukasi merupakan sebuah permainan yang dirancang untuk mengajarkan pemainnya mengenai topik tertentu, memahami sebuah peristiwa sejarah atau budaya, memperkuat pembangunan, membentuk karakteristik, memperluas konsep atau dapat membantu dalam belajar keterampilan karena mereka bermain [4]. Dalam hal ini game simulasi ini merupakan salah satu media edukasi yang baik bagi masyarakat agar mengetahui cara untuk menyelamatkan diri saat terjadi gempa bumi. Game bergenre simulasi ini bertujuan untuk mensimulasikan apa yang akan terjadi pada dunia nyata, game simulasi juga dipakai untuk menentukan keputusan, seperti di kepolisian dipakai sebagai ujian pengambilan Surat Izin Mengemudi, simulasi pilot yang mengendarai pesawat.

Dalam penelitian yang dilakukan oleh Tuti Anggriani Utama, tentang Kesiapsiagaan Masyarakat Lempuing Menghadapi Bencana Gempa Bumi, kesiap siagaan masyarakat menghadapi dampak bencana di wilayah Lempuing kota Bengkulu sebanyak $66 \%$ tidak siap menghadapi bencana gempa bumi [5]. Hasil penelitian yang dilakukan oleh Loviga Denny Pratama, mengenai Game Edukasi: Apakah membuat belajar lebih menarik?, yang hasilnya adalah bahwa media game edukasi di lingkungan sekolah Probolinggo sangat dibutuhkan dan memiliki respon positif dari akademisi Probolinggo, dapat dikatakan bahwa game edukasi dapat memungkinkan belajar lebih menarik [6]. Dalam penelitian yang dilakukan oleh Siti Martatiani Muyasaroh, tentang Game Edukasi Mitigasi Bencana Kebakaran Berbasis Android, yang hasilnya adalah edugame mitigasi bencana kebakaran yang berbasis android dengan nama Boim Sang Penakluk Api dapat menambah pengetahuan tentang mitigasi bencana kebakaran [7]. Dalam penelitian yang dilakukan oleh Dian Lusiana Romdhonah, tentang Pengaruh Edukasi Managemen Bencana Gempa Bumi Terhadap Kesiap siagaan Siswa Dalam Menghadapi Gempa Bumi, yang hasilnya adalah adanya pengaruh tingkat kesiapsiagaan pre and post test pada kelompok kontrol dan kelompok intervensi [8]. Dalam penelitian yang dilakukan oleh Fika Nur Indriasari, tentang Pengaruh Pemberian Metode Simulasi Siaga Bencana Gempa Bumi Terhadap Kesiap Siagaan Anak di Yogyakarta, yang hasilnya adalah pemberian metode simulasi siaga bencana gempa bumi memberikan pengaruh positif dengan kategori lemah terhadap kesiapsiagaan menghadapi bencana gempa bumi pada anak-anak [9].

Berdasarkan hasil dari beberapa penelitian terdahulu, maka dilakukan pembuatan Aplikasi simulasi yang cocok untuk mengedukasi masyarakat agar dapat mengetahui cara-cara yang benar untuk menghadapi gempa bumi dan memberikan pengetahuan cara menyelamatkan diri saat terjadinya gempa bumi di suatu lokasi dengan perantara game simulasi. 


\section{METODE PENELITIAN}

Metodologi yang digunakan adalah metodologi Prototyping karena untuk melakukan identifikasi masalah yang ada pada setiap kejadian gempa bumi, dimana pada setiap gempa mempunyai penyelesaian yang berbeda. Prototyping merupakan adalah bagian dari produk yang mengekspresikan logika maupun fisik antarmuka eksternal yang ditampilkan. Konsumen potensial menggunakan prototyping dan menyediakan masukan untuk tim pengembang sebelum pengembangan skala besar dimulai [10].

\subsection{Pengumpulan Data}

Pada tahap ini, dilakukan pengumpulkan data mengenai kasus gempa bumi yang sering terjadi dan tingkatan dalam gempa bumi serta cara menyelamatkan diri jika terjadi gempa bumi berdasarkan keadaan, untuk kebutuhan perancangan permainan sesuai dengan alur cerita dan storyboard, serta mengidentifikasi kebutuhan sistem dalam proses pembuatan game.

\subsection{Perancangan Prototype}

Pada tahap ini, dilakukan perancangan sistem, use case diagram permainan, sequence diagram, activity diagram dan perancangan aplikasi yang termasuk dalam pembuatan Experience/theme, background story, mechanic, gameplay dan rule \& level.

\subsubsection{Use Case}

Tujuan dari pengguna use case adalah untuk menggambakan interaksi antara pengguna dengan sistem untuk mencapai suatu tujuan tertentu. Diagram use case pada pembuatan game penyelamatan diri dari gempa bumi terdiri dari menu utama, mulai permainan, panduan keselamatan.

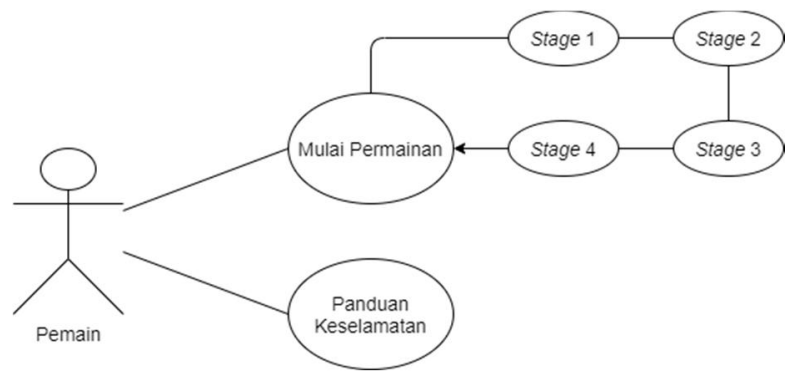

Gambar 1. Diagram Use Case Game

\subsubsection{Sequence Diagram}

Dalam pembuatan sequence diagram untuk memperjelas keterkaitan, alur dan responden dari setiap bagian use case. Berikut adalah sequence diagram pada game yang dibuat.

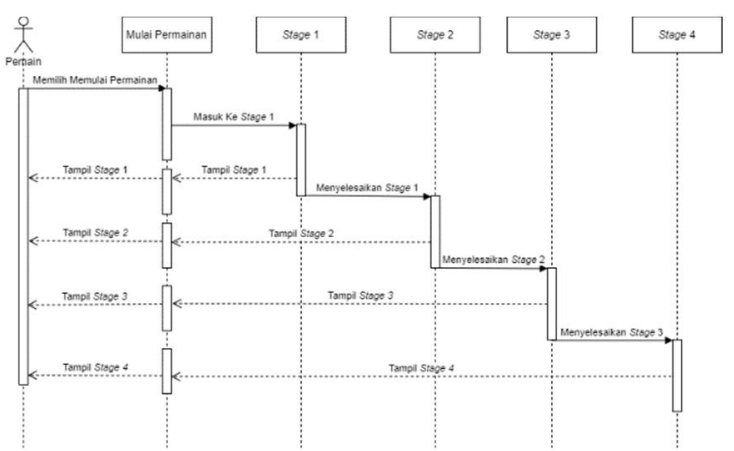

(a)

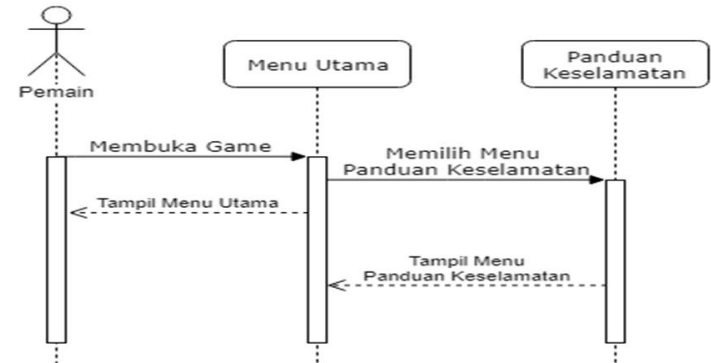

(b)

Gambar 2. Sequence Diagram Mulai Permainan (a), Sequence Diagram Panduan Keselamatan (b). 


\subsubsection{Activity Diagram}

Activity Diagram dapat menggambarkan berbagai alur aktivitas dalam sistem Activity Diagram yang telah dirancang, baik dari pertama sistem berjalan, percabangan proses dimana mungkin terjadi dan hingga bagaimana proses tersebut akan berakhir. Activity Diagram yang dirancang terdiri dari activity membuka menu permainan, menu bantuan, menu tampilan intro level dan mulai permainan.

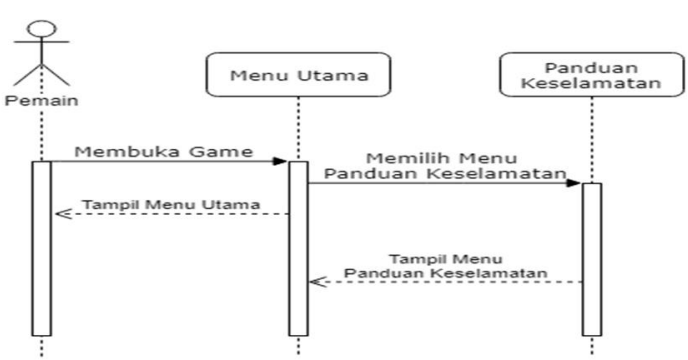

(a)



(b)

Gambar 3. Activity diagram Panduan Keselamatan (a), Activity diagram Menu Mulai Permainan (b).

\subsection{Evaluasi Prototyping}

Pada tahap ini, dilakukan pemeriksaan apakah rancangan prototype dan skenario game sudah sesuai kebutuhan atau tidak. Jika tidak, maka akan mengulangi langkah awal. Jika sudah sesuai, maka akan dilanjutkan ke langkah selanjutnya.

\subsubsection{Storyboard}

Story pada game penyelamatan diri dari gempa bumi disajikan dalam bentuk storyboard, yaitu adegan game. Adapun storyboard yang dimaksud dapat dilihat sebagai berikut.

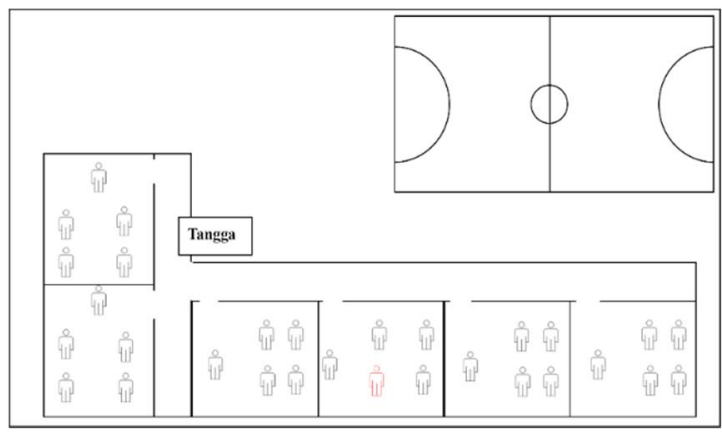

(a)

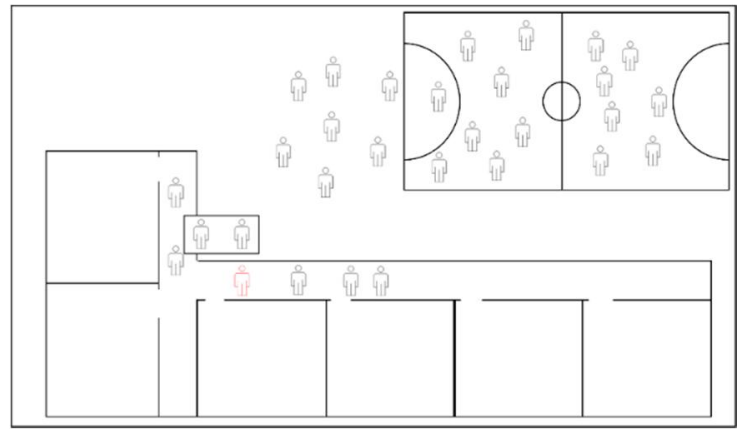

(b) 


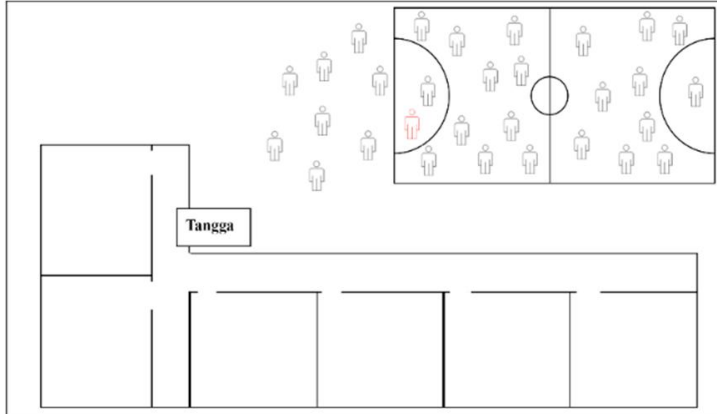

(c)

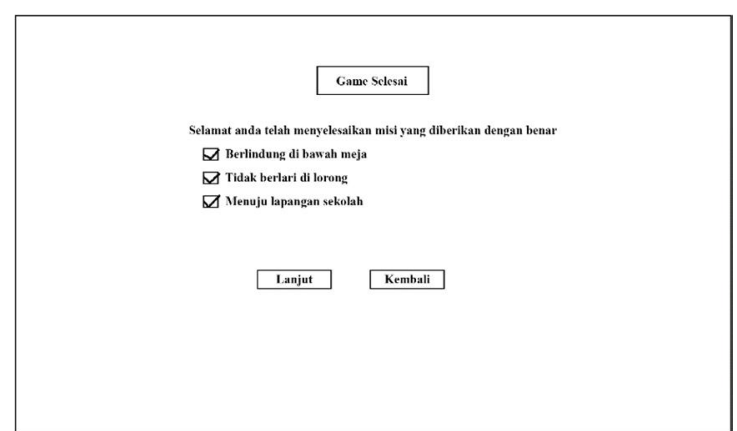

(d)

Gambar 4. Stage 1 Mulai Permainan (a), Stage 1 Pemain Menuju Tangga (b), Stage 1 Pemain Menuju Lapangan (c), Stage 1 Stage Berhasil.

Gambar 4 (a) menunjukan suasanan belajar, pada tahap ini gempa bumi akan terjadi, saat gempa bumi terjadi akan ada narasi berupa tulisan yang bemberitahukan sedang terjadi gempa bumi, pemain diharuskan berlindung dibawah meja untuk menyelesaikan misi pertama, Gambar 4 (b) pada tampilan ini gempa bumi sudah tidak terasa lagi, untuk menyelesaikan misi kedua pemain tidak di perbolehkan berlari dilorong lantai dua. Gambar 4 (c) pada tampilan ini pemain menuju ke lapangan sekolah untuk menyelesaikan misi ke-tiga. Gambar 4 (d) pada tampilan ini pemain berhasil menyelesaikan semua misi dan dapat menuju ke stage selanjutnya.

\subsection{Perancangan Sistem}

Pada tahap ini, dilakukan pengkodean pada rancangan prototype yang telah dibuat, dengan melakukan sinkronisasi antar desain antarmuka game, desain karakter, desain situasi tempat, audio, dan pengkodean sesuai dengan skenario pada permainan. Aplikasi dibangun denga menggunakan Unity 3D sebagai game engine, Adobe photoshop sebagai pengolah gambar dan $\mathrm{C} \#$ sebagai bahasa pemrograman yang digunakan.

\section{A. Unity $3 D$}

Unity 3D merupakan sebuah aplikasi yang meringankan dan memudahkan game developer dalam merancang atau membuat sebuah game. Unity 3D adalah sebuah game engine/game authoring tool yang dapat mendukung orang kreatif untuk membangun sebuah video game [11].

\section{B. Adobe photoshop}

Adobe Photoshop adalah program aplikasi untuk mendesain yang digunakan untuk mengolah foto digital, mendesain gambar dan mengedit image grafis. Perangkat lunak ini juga banyak digunakan oleh fotohrafer digital dan perusahaan iklan sehingga dianggap sebagai pemimpin pasar (market leader) untuk perangkat lunak pengolah gambar/foto, yang dianggap sebagai produk terbaik yang pernah diproduksi oleh Adobe Systems [12].

\section{Bahasa Pemrograman C\#}

C\# adalah Bahasa pemrograman umum berorientasi objek, dibuat dan dikembangkan oleh Microsoft bersama dengan platform .NET. Ada perangkat lunak yang sangat beragam dikembangkan dengan menggunakan C\# dan platform .NET. seperti aplikasi web, aplikasi desktop, game, dan lain-lain [13].

\subsection{Pengujian Sistem}

Pada tahap ini, dilakukan pengujian pada permainan yang telah dibuat dan memastikan permainan yang telah dibuat berjalan dan sesuai tujuan. 


\section{HASIL DAN PEMBAHASAN}

\subsection{Perancangan dan Alur Game}

Berikut ini merupakan hasil akhir dari rancangan game Penyelamatan diri dari gempa bumi, adapun tampilan game ini dapat dilihat sebagai berikut.

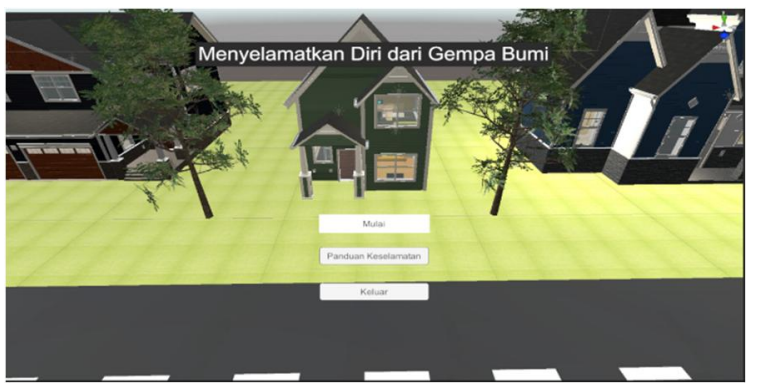

(a)

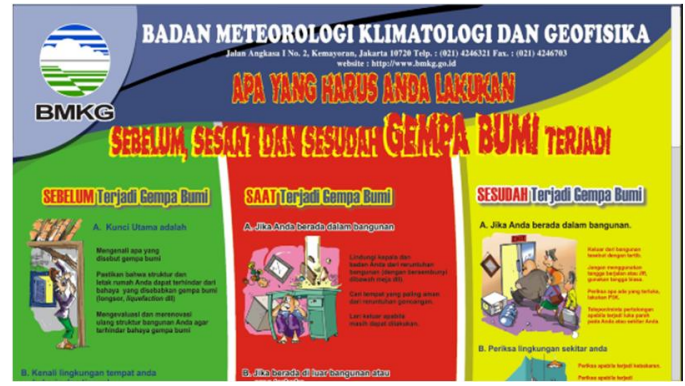

(b)

Gambar 5. Tampilan Menu Utama (a), Tampilan Panduan Keselamatan (b).

Gambar 5 (a) akan muncul saat membuka aplikasi permainan, terdapat tiga tombol pada tampilan menu utama yaitu mulai untuk memulai permainan dan menuju ke stage 1, panduan keselamatan untuk menuju ke halaman panduan keselamatan dan keluar untuk menutup aplikasi. Pada tampilan 5 (b) merupakan tampilan panduan keselamatan yang isinya adalah cara menyelamatkan diri dari gempa bumi.

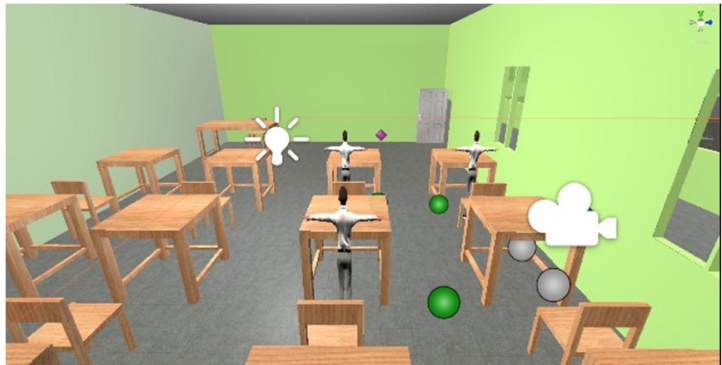

(a)

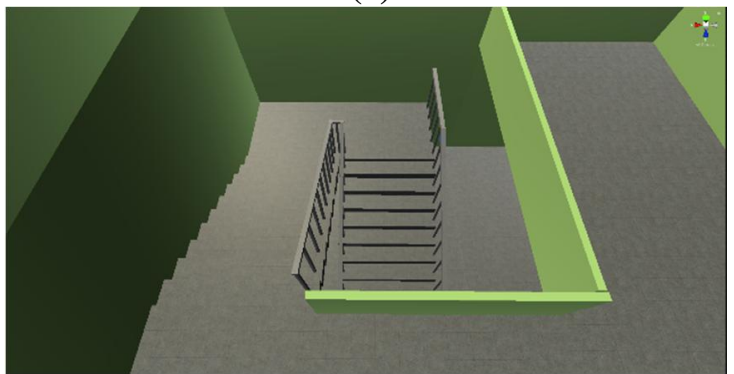

(c)

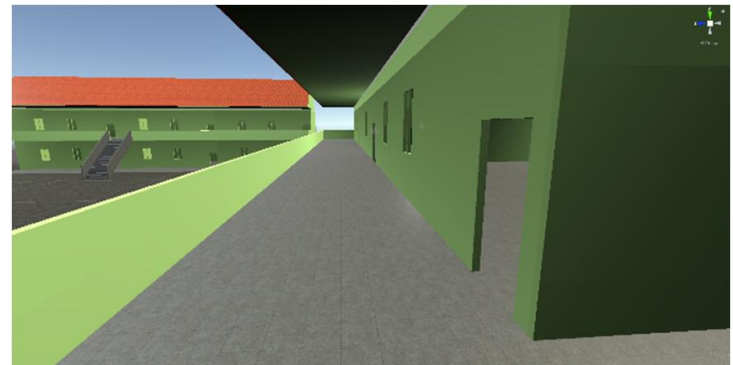

(b)

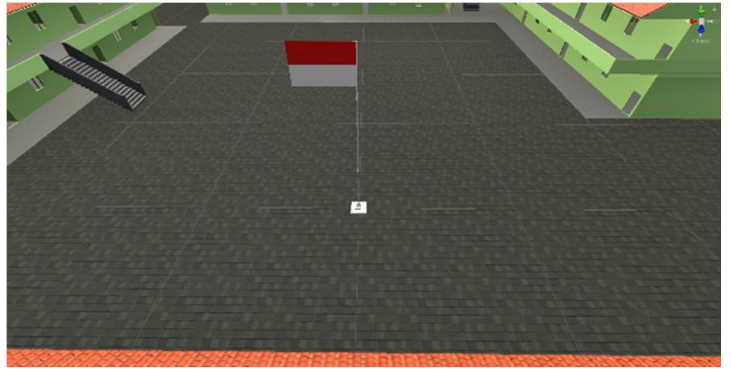

(d)

Gambar 6. Stage 1 Ruang Kelas (a), Stage 1 Koridor Lantai Dua (b), Stage 1 Tangga Lantai Dua (c), Stage 1 Lapangan Sekolah (d).

Gambar 6 (a) merupakan tampilan salah satu ruangan kelas pada lantai dua sekolah, pada ruangan ini stage satu akan dimulai, pada tahap ini gempa bumi akan terjadi, saat gempa bumi terjadi akan ada narasi berupa tulisan yang bemberitahukan sedang terjadi gempa bumi, pemain diharuskan berlindung dibawah meja untuk menyelesaikan misi pertama. Gambar 6 (b) merupakan tampilan koridor lantai dua, disini pemain tidak diperbolehkan berlari untuk menyelsaikan misi kedua. Gambar 6 (c) merupakan tampilan tangga yang akan dilewati setelah melewati koridor lantai dua untuk menuju lapangan. Gambar 6 (d) merupakan tampilan 
lapangan sekolah yang menjadi tujuan akhir dari pemain, pada saat pemain sampai pada lapangan dan menyelesaikan semua misi, pemain dapat melanjutkan ke Stage selanjutnya.

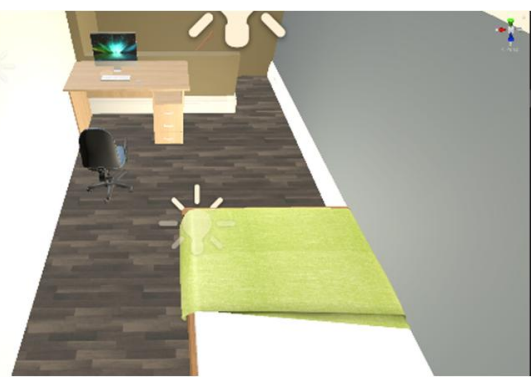

(a)



(c)

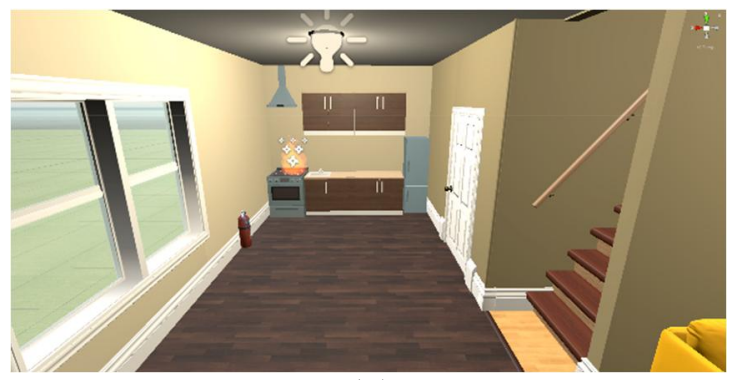

(b)

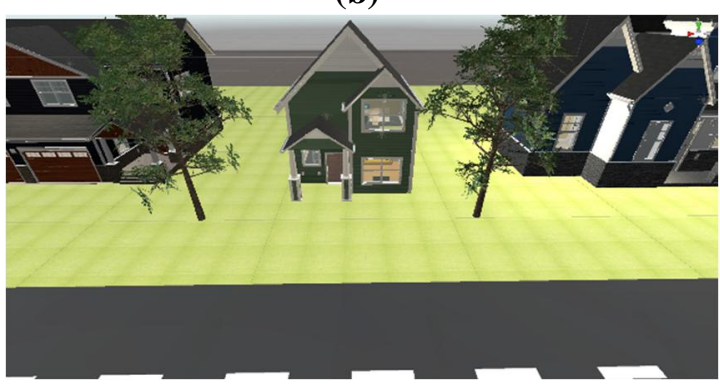

(d)

Gambar 7. Stage 2 Kamar Lantai 2 (a), Stage 2 Dapur (b), Stage 2 Ruang Tamu (c), Stage 2 Luar Rumah (d).

Gambar 7 (a) merupakan tampilan sebuah ruang kamar yang di ruangan inilah akan dimulainya permainan dari stage dua., pada tahap ini gempa bumi akan terjadi, saat gempa bumi terjadi akan ada narasi berupa tulisan yang bemberitahukan sedang terjadi gempa bumi, pemain diharuskan berlindung dibawah meja untuk menyelesaikan misi pertama. Gambar 7 (b) merupakan tampilan ruang dapur yang akan terjadinya kebakaran di ruangan ini, disini pemain harus memadamkan api dengan menggunakan alat pemadam kebakaran untuk menyelsaikan misi kedua. Gambar 7 (c) merupakan tampilan ruangan tamu yang akan dilewati untuk menuju ke luar rumah dan menyelesaikan misi ke tiga. Gambar 7 (d) merupakan kondisi di sekeliling rumah, pada saat pemain berada diluar rumah pemain harus menuju lapangan untuk menyelesaikan misi ke empat. Pada saat pemain sudah berada dilapangan dan menyelesaikan semua misi, pemain dapat melanjutkan ke Stage selanjutnya.

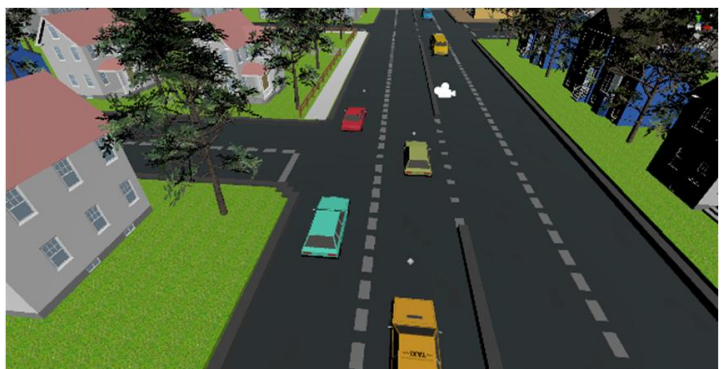

(a)

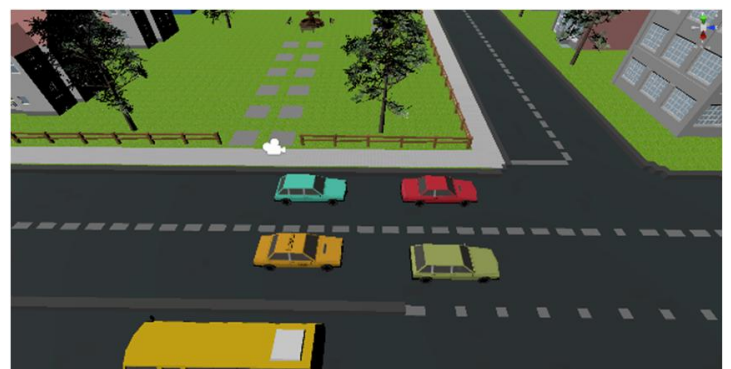

(b) 


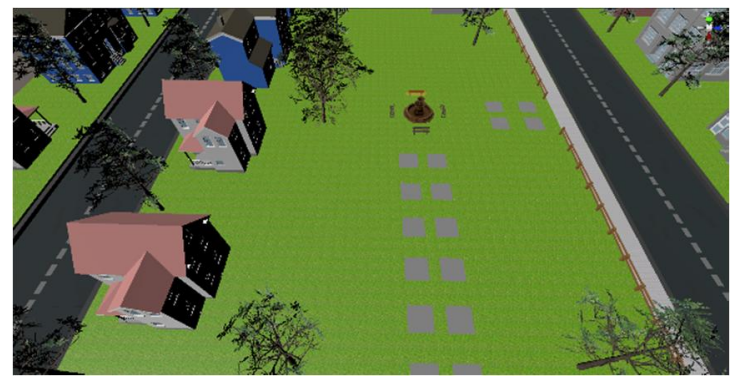

(c)

Gambar 8. Stage 3 Jalan Raya (a), Stage 3 Lampu Merah (b), Stage 3 Lapangan (c),

Gambar 8 (a) merupakan tampilan jalan raya, dimana pemain akan memulai stage tiga, pada tahap ini pemain memainkan karakter utama yang sedang mengendarai mobil dijalan raya. Gambar 8 (b) merupakan tampilan pemain yang di lampu merah dimana akan terjadi gempa bumi, disini pemain harus harus keluar dari mobil untuk menyelesaikan misi pertama. Gambar 8 (c) merupakan tampilan lapangan yang akan dituju pemain untuk menyelesaikan misi ke dua, pada saat pemain berada dilapangan dan menyelesaikan semua misi, pemain dapat melanjutkan ke Stage selanjutnya.

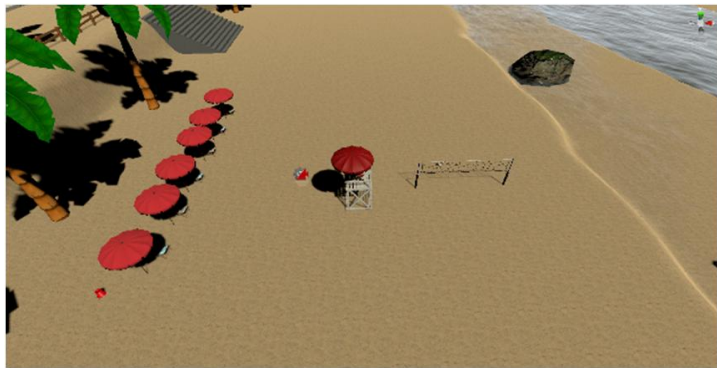

(a)

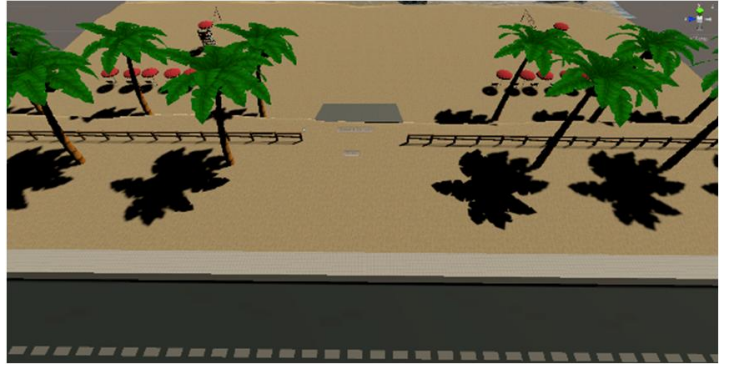

(b)

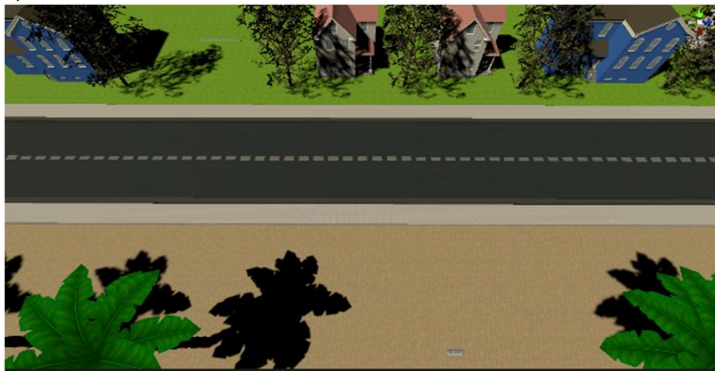

(c)

Gambar 9. Stage 4 Pantai (a), Stage 4 Dataran tinggi (b), Stage 4 Perumahan (c),

Gambar 9 (a) merupakan tampilan sebuah pantai, dimana pemain akan memulai stage empat, pada tahap ini pemain sedang berada dipantai saat gempa bumi terjadi akan ada narasi berupa tulisan yang bemberitahukan sedang terjadi gempa bumi. Gambar 9 (b) merupakan tampilan dataran tinggi, pemain harus menuju dataran tinggi untuk menyelesaikan misi pertama. Gambar 9 (c) merupakan tampilan merupakan perumahan yang mempunyai lapangan kosong yang menjadi tujuan dari misi ke dua, pada saat pemain berada dilapangan dan menyelesaikan semua misi, pemain telah menyelesaikan permainan.

\subsection{Pengujian}

Dalam tahap pengujian sistem dilakukan pengujian pada permainan yang telah dibuat dan memastikan permainan yang telah dibuat berjalan dan sesuai tujuan. 


\subsubsection{Uji Kompatibilitas}

Pada tahap pengujian ini dilakukan pengujian terhadap kompatibilitas dari aplikasi yang telah dibangaun untuk mengukur spesifikasi mana saja yang dapat digunakan untuk menginstal aplikasi. Setelah melakukan pengujian adapun spesifikasi yang digunakan dalam pembuatan aplikasi seperti pada tabel 1 .

Tabel 1. Spesifikasi Perangkat Keras Untuk Menjalankan Aplikasi

\begin{tabular}{|c|c|c|}
\hline No & Perangkat Keras & Spesifikasi \\
\hline 1. & Processor & 4 Core \\
\hline 2. & RAM & $4 \mathrm{~GB}$ \\
\hline 3. & Memory & $1 \mathrm{~GB}$ \\
\hline
\end{tabular}

\subsubsection{Metode Pengujian}

Metode pengujian menggunakan black-box testing untuk mengetahui keluaran masukan sistem apakah sudah berfungsi sesuai keinginan. Hasil pengujian dapat dilihat pada tabel 2 .

Tabel 2. Hasil Black-Box Testing

\begin{tabular}{|c|c|c|c|c|}
\hline No & Nama Pengujian & Hasil yang diinginkan & Hasil yang Didapatkan & Keterangan \\
\hline 1 & $\begin{array}{l}\text { Aplikasi } \\
\text { Membuka Dan } \\
\text { Menjalankan. }\end{array}$ & $\begin{array}{l}\text { Menampilkan halaman } \\
\text { menu utama. }\end{array}$ & $\begin{array}{l}\text { Menampilkan halaman } \\
\text { menu utama. }\end{array}$ & Valid \\
\hline 2 & $\begin{array}{l}\text { Menekan tombol } \\
\text { Panduan } \\
\text { Keselamatan. }\end{array}$ & $\begin{array}{l}\text { Menampilkan menu } \\
\text { panduan keselamatan. }\end{array}$ & $\begin{array}{l}\text { Menampilkan menu } \\
\text { panduan keselamatan. }\end{array}$ & Valid \\
\hline 3 & $\begin{array}{l}\text { Menekan Tombol } \\
\text { Mulai }\end{array}$ & Menampilkan Stage 1. & Menampilkan Stage 1. & Valid \\
\hline 4 & $\begin{array}{l}\text { Memulai Dialog } \\
\text { Dan Menekan } \\
\text { Tombol Lanjut } \\
\text { Pada Stage 1 }\end{array}$ & Melanjutkan dialog. & Melanjutkan dialog. & Valid \\
\hline 5 & $\begin{array}{l}\text { Melakukan Misi } \\
1 \text { pada stage } 1\end{array}$ & $\begin{array}{l}\text { Menampilkan text } \\
\text { berhasil atau gagal } \\
\text { pada text misi. }\end{array}$ & $\begin{array}{l}\text { Menampilkan text } \\
\text { berhasil atau gagal pada } \\
\text { text misi. }\end{array}$ & Valid \\
\hline 6 & $\begin{array}{l}\text { Melakukan Misi } \\
2 \text { Pada Stage } 1\end{array}$ & $\begin{array}{l}\text { Menampilkan text } \\
\text { berhasil atau gagal } \\
\text { pada text misi maka } \\
\text { misi berhasil. }\end{array}$ & $\begin{array}{l}\text { Menampilkan text } \\
\text { berhasil atau gagal pada } \\
\text { text misi maka misi } \\
\text { berhasil. }\end{array}$ & Valid \\
\hline 7 & $\begin{array}{l}\text { Melakukan Misi } \\
3 \text { Pada Stage } 1\end{array}$ & $\begin{array}{l}\text { Menampilkan text } \\
\text { berhasil atau gagal } \\
\text { pada text misi. }\end{array}$ & $\begin{array}{l}\text { Menampilkan text } \\
\text { berhasil atau gagal pada } \\
\text { text misi. }\end{array}$ & Valid \\
\hline 8 & $\begin{array}{l}\text { Menampilkan } \\
\text { Tampilan Misi } \\
\text { Berhasil Pada } \\
\text { Stage 1 }\end{array}$ & $\begin{array}{l}\text { Menampilkan tampilan } \\
\text { misi berhasil. }\end{array}$ & $\begin{array}{l}\text { Menampilkan tampilan } \\
\text { misi berhasil. }\end{array}$ & Valid \\
\hline 9 & $\begin{array}{l}\text { Menguji Tombol } \\
\text { Pada Tampilan } \\
\text { Berhasil Stage } 1\end{array}$ & $\begin{array}{l}\text { Kembali ke menu } \\
\text { utama, mengulangi } \\
\text { stage } 1 \text {, menampilkan } \\
\text { stage } 2 \text {. }\end{array}$ & $\begin{array}{l}\text { Kembali ke menu utama, } \\
\text { mengulangi stage } 1 \text {, } \\
\text { menampilkan stage } 2 \text {. }\end{array}$ & Valid \\
\hline 10 & $\begin{array}{l}\text { Memulai Dialog } \\
\text { Dan Menekan }\end{array}$ & Melanjutkan dialog. & Melanjutkan dialog. & Valid \\
\hline
\end{tabular}

Marzali, et., al (Perancangan Aplikasi Simulasi Penyelamatan Diri Dari Gempa Bumi) 


\begin{tabular}{|c|c|c|c|c|}
\hline No & Nama Pengujian & Hasil yang diinginkan & Hasil yang Didapatkan & Keterangan \\
\hline & $\begin{array}{l}\text { Tombol Lanjut } \\
\text { Pada Stage } 2\end{array}$ & & & \\
\hline 11 & $\begin{array}{l}\text { Melakukan Misi } \\
1 \text { Pada Stage } 2\end{array}$ & $\begin{array}{l}\text { Menampilkan text } \\
\text { berhasil atau gagal } \\
\text { ada text misi. }\end{array}$ & $\begin{array}{l}\text { Menampilkan text } \\
\text { berhasil atau gagal pada } \\
\text { text misi. }\end{array}$ & Valid \\
\hline 12 & $\begin{array}{l}\text { Melakukan Misi } \\
2 \text { Pada Stage } 2\end{array}$ & $\begin{array}{l}\text { Menampilkan text } \\
\text { berhasil atau gagal } \\
\text { pada text misi. }\end{array}$ & $\begin{array}{l}\text { Menampilkan text } \\
\text { berhasil atau gagal pada } \\
\text { text misi. }\end{array}$ & Valid \\
\hline 13 & $\begin{array}{l}\text { Melakukan Misi } \\
3 \text { Pada Stage } 2\end{array}$ & $\begin{array}{l}\text { Menampilkan text } \\
\text { berhasil atau gagal } \\
\text { pada text misi. }\end{array}$ & $\begin{array}{l}\text { Menampilkan text } \\
\text { berhasil atau gagal pada } \\
\text { text misi. }\end{array}$ & Valid \\
\hline 14 & $\begin{array}{l}\text { Melakukan Misi } \\
4 \text { Pada Stage } 2\end{array}$ & $\begin{array}{l}\text { Menampilkan text } \\
\text { berhasil atau gagal } \\
\text { pada text misi. }\end{array}$ & $\begin{array}{l}\text { Menampilkan text } \\
\text { berhasil atau gagal pada } \\
\text { text misi. }\end{array}$ & Valid \\
\hline 15 & $\begin{array}{l}\text { Menampilkan } \\
\text { Tampilan Misi } \\
\text { Berhasil Pada } \\
\text { Stage } 2\end{array}$ & $\begin{array}{l}\text { Menampilkan tampilan } \\
\text { misi berhasil. }\end{array}$ & $\begin{array}{l}\text { Menampilkan tampilan } \\
\text { misi berhasil. }\end{array}$ & Valid \\
\hline 16 & $\begin{array}{l}\text { Menguji Tombol } \\
\text { Pada Tampilan } \\
\text { Berhasil Stage } 2\end{array}$ & $\begin{array}{l}\text { Kembali ke menu } \\
\text { utama, mengulangi } \\
\text { stage 2, menampilkan } \\
\text { stage } 3 \text {. }\end{array}$ & $\begin{array}{l}\text { Kembali ke menu utama, } \\
\text { mengulangi stage } 2 \text {, } \\
\text { menampilkan stage } 3 \text {. }\end{array}$ & Valid \\
\hline 17 & $\begin{array}{l}\text { Memulai Dialog } \\
\text { Dan Menekan } \\
\text { Tombol Lanjut } \\
\text { Pada Stage } 3\end{array}$ & Melanjutkan dialog. & Melanjutkan dialog. & Valid \\
\hline 18 & $\begin{array}{l}\text { Melakukan Misi } \\
1 \text { Pada Stage } 3\end{array}$ & $\begin{array}{l}\text { Menampilkan text } \\
\text { berhasil atau gagal } \\
\text { ada text misi. }\end{array}$ & $\begin{array}{l}\text { Menampilkan text } \\
\text { berhasil atau gagal pada } \\
\text { text misi. }\end{array}$ & Valid \\
\hline 19 & $\begin{array}{l}\text { Melakukan Misi } \\
2 \text { Pada Stage } 3\end{array}$ & $\begin{array}{l}\text { Menampilkan text } \\
\text { berhasil atau gagal } \\
\text { pada text misi. }\end{array}$ & $\begin{array}{l}\text { Menampilkan text } \\
\text { berhasil atau gagal pada } \\
\text { text misi. }\end{array}$ & Valid \\
\hline 20 & $\begin{array}{l}\text { Menampilkan } \\
\text { Tampilan Misi } \\
\text { Berhasil Pada } \\
\text { Stage } 3\end{array}$ & $\begin{array}{l}\text { Menampilkan tampilan } \\
\text { misi berhasil. }\end{array}$ & $\begin{array}{l}\text { Menampilkan tampilan } \\
\text { misi berhasil. }\end{array}$ & Valid \\
\hline 21 & $\begin{array}{l}\text { Menguji Tombol } \\
\text { Pada Tampilan } \\
\text { Berhasil Stage } 3\end{array}$ & $\begin{array}{l}\text { Kembali ke menu } \\
\text { utama, mengulangi } \\
\text { stage } 3 \text {, menampilkan } \\
\text { stage } 4 .\end{array}$ & $\begin{array}{l}\text { Kembali ke menu utama, } \\
\text { mengulangi stage } 3 \text {, } \\
\text { menampilkan stage } 4 \text {. }\end{array}$ & Valid \\
\hline 22 & $\begin{array}{l}\text { Memulai Dialog } \\
\text { Dan Menekan } \\
\text { Tombol Lanjut } \\
\text { Pada Stage } 4\end{array}$ & Melanjutkan dialog. & Melanjutkan dialog. & Valid \\
\hline 23 & $\begin{array}{l}\text { Melakukan Misi } \\
1 \text { Pada Stage } 4\end{array}$ & $\begin{array}{l}\text { Menampilkan text } \\
\text { berhasil atau gagal } \\
\text { pada text misi. }\end{array}$ & $\begin{array}{l}\text { Menampilkan text } \\
\text { berhasil atau gagal pada } \\
\text { text misi. }\end{array}$ & Valid \\
\hline 24 & $\begin{array}{l}\text { Melakukan Misi } \\
2 \text { Pada Stage } 4\end{array}$ & $\begin{array}{l}\text { Menampilkan text } \\
\text { berhasil atau gagal }\end{array}$ & $\begin{array}{l}\text { Menampilkan text } \\
\text { berhasil atau gagal pada }\end{array}$ & Valid \\
\hline
\end{tabular}




\begin{tabular}{|c|l|l|l|c|}
\hline No & Nama Pengujian & Hasil yang diinginkan & Hasil yang Didapatkan & Keterangan \\
\hline 25 & $\begin{array}{l}\text { Menampilkan } \\
\text { Tampilan Misi } \\
\text { Berhasil Pada } \\
\text { Stage 4 }\end{array}$ & $\begin{array}{l}\text { Menampilkan tampilan } \\
\text { misi berhasil. }\end{array}$ & $\begin{array}{l}\text { Menampilkan tampilan } \\
\text { misi berhasil. }\end{array}$ & Valid \\
\hline 26 & $\begin{array}{l}\text { Menguji tombol } \\
\text { pada tampilan } \\
\text { berhasil stage 3 }\end{array}$ & $\begin{array}{l}\text { Kembali ke menu } \\
\text { utama, mengulangi } \\
\text { stage 4. }\end{array}$ & $\begin{array}{l}\text { Kembali ke menu utama, } \\
\text { mengulangi stage 4. }\end{array}$ & Valid \\
\hline
\end{tabular}

Berdasarkan hasil pengujian dari Tabel 2 hasil Black box Testing, dapat dilihat berapa persentase keberhasilan dari Aplikasi Simulasi Penyelamatan Diri Dari Gempa Bumi dengan cara penghitungan persentase sebagai berikut.

$$
\begin{aligned}
\text { Jumlah Pengujian } & =26 & & \\
\text { Tercapai } & =26 / 26 \times 100 \% & \text { Gagal } & =0 / 26 x \\
& =100 \% & & =0 \%
\end{aligned}
$$

Dari proses penghitungan persentase yang telah dilakukan maka dapat diambil hasilnya berupa persentase keberhasilan dari Aplikasi Simulasi Penyelamatan Diri Dari Gempa Bumi adalah $100 \%$ dan kegagalan nya adalah $0 \%$.

\section{KESIMPULAN}

Perancangan Aplikasi Simulasi Penyelamatan Diri Dari Gempa Bumi ini dapat dijalankan dengan lancar karena telah dilakukan pengujian Black Box yang hasilnya adalah semua fungsi dari aplikasi ini dapat berjalan dengan baik dan sesuai dengan tujuan.

\section{SARAN}

1. Perancangan Aplikasi Simulasi Penyelamatan Diri Dari Gempa Bumi, sebakiknya memperbarui tampilan menu dan menambahkan fitur yang dapat memikat pemain dan tidak membosankan.

2. Aplikasi ini hanya ditujukan untuk pengguna komputer dan tidak dapat dijalankan pada perangkat smartphone, maka akan lebih baik jika bisa dijalankan pula di semua platform dan tidak terbatas hanya di perangkat komputer saja.

3. Menambahkan stage pada permainan sehingga dapat disimulasikan situasi dan kondisi dari gempa bumi lebih beragam lagi.

\section{UCAPAN TERIMA KASIH}

Penulis juga banyak mengucapkan terima kasih kepada semua pihak yang telah membantu baik secara langsung maupun tidak langsung, juga kepada pihak-pihak yang telah memberikan bimbingan, pengarahan, maupun ide-ide untuk penulis selama proses penyelesaian laporan skripsi ini, terutama kepada:

1. Bapak Johannes Petrus, S.Kom, M.T.I., selaku Ketua STMIK Global Informatika MDP.

2. Ibu Desy Iba Ricoida, ST., M.T.I, selaku Wakil Ketua I STMIK Global Informatika MDP Palembang. 
3. Ibu Kathryn Sugara, S.E., M.Si, selaku Wakil Ketua II STMIK Global Informatika MDP Palembang.

4. Bapak Dedy Hermanto, S.Kom, M.T.I, selaku Wakil Ketua III STMIK Global Informatika MDP Palembang.

5. Ibu Yoannita, M.Kom., selaku Ketua Program Studi Teknik Informatika STMIK Global Informatika MDP Palembang.

6. Bapak Daniel Udjulawa, S.Kom., M.T.I, selaku Pembimbing Utama yang telah bersedia membimbing penulis untuk konsultasi dan koreksi laporan skripsi ini.

7. Segenap Dosen STMIK Global Informatika MDP Palembang yang telah memberikan bimbingan akademik kepada penulis selama perkuliahan.

8. Segenap Dosen STMIK GI MDP Palembang yang telah memberikan bimbingan akademik selama perkuliahan.

9. Orang tua, saudara dan kerabat yang telah memberikan dukungan dan semangat kepada penulis dalam menyelesaikan laporan skripsi ini.

10. Teman-teman yang selalu membantu dan memberi dukungan yang berarti dalam penulisan laporan skripsi ini yang tidak dapat disebutkan satu per satu.

\section{DAFTAR PUSTAKA}

[1] Erlangga. 2007, Gempa Bumi, Erlangga, Jakarta.

[2] Kementerian Keuangan Republik Indonesia. 2020, Masuk Peringkat 37 Negara Rentan Bencana, Pemerintah Indonesia Asuransikan Asetnya, https://www.djkn.kemenkeu.go.id/berita/baca/21851/Masuk-Peringkat-37-Negara-

Rentan-Bencana-Pemerintah-Indonesia-Asuransikan-Asetnya.html, Diakses 10 Januari 2021.

[3] Nugroho. 2018, Gempa 5,4 SR dan 6,5 SR, Kembali Guncang Lombok, https://bnpb.go.id/berita/gempa-54-sr-dan-65-sr-kembali-guncang-lombok, Diakses 10 Januari 2021.

[4] Adams, Ernest. 2010, Fundamentals of Game Desing, Barkeley, New Riders.

[5] Tuti Anggriani Utama, 2019, Kesiapsiagaan Masyarakat Lempuing Menghadapi Bencana Gempa Bumi, Program Studi D3 Keperawatan FMIPA Universitas Bengkulu, Bengkulu.

[6] Loviga Denny Pratama. 2019, Game Edukasi: Apakah Membuat Belajar Lebih Menarik?, Institut Ilmu Keislaman Zainul Hasan Genggong, Probolinggo.

[7] Siti Martatiani Muyasaroh. 2019, Game Edukasi Mitigasi Bencana Kebakaran Berbasis Android, Fakultas Komunikasi dan Informatika Universitas Muhammadiyah, Surakarta.

[8] Dian Lusiana Romdhonah, 2019, Pengaruh Edukasi Managemen Bencana Gempa Bumi Terhadap Kesiapsiagaan Siswa Dalam Menghadapi Gempa Bumi, FIKES Universitas Respati, Yogyakarta.

[9] Fika Nur Indriasari. 2016, Pengaruh Pemberian Metode Simulasi Siaga Bencana Gempa Bumi Terhadap Kesiapsiagaan Anak di Yogyakarta, Departemen Keperawatan Anak/Akper Notokusumo, Yogyakarta. 
[10] Simarmata, Janner, 2010, Rekayasa Perangkat Lunak, Andi Offset, Yogyakarta.

[11] Creighton, Ryan Henson, 2011, Unity 3D: Beginner's Guide: A Seat of Your Pants Manual for, Packt Pub.

[12] Hakim, Zainal, 2012. Sejarah Adobe Photoshop, PT. Gramedia, Jakarta.

[13] Nakov, Svetlin, 2013, Fundamentals of Programming with c\# and Java, Faber Publishing, Bulgarian. 